\title{
$>$ Um estudo sobre três premissas do argumento ateu na peça $O$ berço do herói, de Dias Gomes
}

$>$ Three premises of the atheist argument in Dias Gomes's play O berço do herói: A study.

\author{
por Ricardo Cortez Lopes \\ Doutorando em Sociologia pela Universidade Federal do Rio Grande do Sul (UFRGS). \\ E-mail: rshicardo@hotmail.com. ORCID: 0000-0003-0808-7203. \\ por Lis Yana de Lima Martinez \\ Doutoranda em Estudos de Literatura pelo Programa de Pós-Graduação do Instituto de \\ Letras UFRGS. E-mail: yana.flafy@gmail.com. ORCID: 0000-0001-6608-257X.
}

\begin{abstract}
Resumo
Ascendendo no campo teórico desde a virada do milênio, o ateísmo tem sido considerado uma variedade religiosa de relevância social e acadêmica por razões estigmatizantes. Este artigo apresenta um estudo com enfoque nos espaços da etapa incipiente do ateísmo como opção religiosa. Para tanto, analisamos a peça O berço do herói, de Dias Gomes. Essa peça é inspirada em um caso real que aconteceu durante a Guerra dos Canudos. Nela, é possível observar como Dias Gomes, autor que se afirmou publicamente como ateu e marxista, constrói um argumento ateu-marxista baseado em três premissas, demonstradas pela verossimilhança da situação.
\end{abstract}

Palavras-chave: O berço do herói. Argumento ateu. Religião. Nacionalismo.

\begin{abstract}
Rising in the theoretical field since the turn of the millennium atheism has been considered a religious variety of social and academic relevance for stigmatizing reasons. This paper presents a study focusing on the spaces of atheism as a religious option. The analysed corpus is $O$ berço do herói, written by Dias Gomes and inspired by a real case that happened during The War of Canudos. By its plot, it is possible to observe how Dias Gomes, who has publicly asserted himself as an atheist and Marxist, builds an atheistMarxist argument based on three premises that are demonstrated by the likelihood of the situation.
\end{abstract}

Keywords: O berço do herói. Atheist argument. Religion. Nationalism. 


\section{Introdução}

O fazer criativo de Dias Gomes ocorre por camadas, pela lapidação e reescrita intertextual de suas próprias criações. Na trajetória entre $O$ berço do herói e Roque Santeiro, vemos a costura integrativa dos discursos referenciados em Metafísica e na Poética, de Aristóteles. Ou seja, "o discurso com sentido referencial, que fala do mundo (a filosofia, a história, por exemplo) e o discurso com sentido não referencial, que fala de seu próprio mundo - que ele elabora -, e que é sua própria referência"1. O discurso referencial se aproxima ou se afasta dos textos à medida que Dias Gomes alinha suas alterações e proposições. Neste artigo, todavia, caberá trazermos apontamentos mais voltados à peça $O$ berço do herói.

Ateu, o autor deixa transparecer, em suas obras, argumentos estruturais e de composição engendrados por meio de um duplo ataque ao mito religioso visto que o herói adquire significado religioso - em geral em sua faticidade: (I) psicológico, por meio de Ludwig Feuerbach (mais explícito na descrição da religiosidade da personagem Mocinha) e (II) materialista-dialética, por meio de Marx (pela força da elite local). Assim, o mito religioso é atacado por meio do argumento ateu-marxista, segundo o qual há, basicamente, uma farsa montada a partir da ficção religiosa que esconde a exploração. Esse ponto será aprofundado no decorrer do texto, apelando justamente para Marx e Feuerbach, autores importantes para o pensamento marxista. O percurso do texto é entender o ateísmo como variedade religiosa, passando pelos três Roques para culminar na análise do ateísmo em $O$ berço do herói.

\footnotetext{
${ }^{1}$ Thiphaine Samoyault, A intertextualidade, 2008, p. 102.
} 


\section{Ateísmo como variedade religiosa: das etapas para as representações sociais circulantes}

O ateísmo tem ganhado certo destaque público na cena brasileira por ser, muitas vezes, utilizado como adjetivo pejorativo, ao invés de uma identidade complexa e viável - uma negação vazia de conteúdo. Muitos autores tentam, por seu turno, demonstrar a existência de (1) um pensamento sistemático ateu e (2) a existência de um grupo com valores compartilhados. Este artigo intenta contribuir para esse objeto de estudos ao investigar a fundo um caso específico de ateísmo no diálogo com uma teoria maior.

Essa teoria, a ser aprofundada posteriormente, afirma que o ateísmo, no caso brasileiro, assume três etapas no tempo histórico, respondentes ao modo como o estado conceitua (ou não) a religião. Nosso foco recai na configuração denominada como incipiente, que é um ateísmo que não se quer (ou não pode ser) explicitamente público. Essa configuração, em específico, não se advoga publicamente como ateia, porém divulga a pertença, apresenta-a por meio de metáforas de sua mensagem principal. O caso empírico ao qual faremos referência é o texto da peça $O$ berço do herói, de Alfredo de Freitas Dias Gomes (1922 - 1999), ateu que fez parte do partido comunista. Essa peça é estruturada por um argumento ateu e seus acontecimentos, que se pretendem verossimilhantes.

Basicamente, dois acontecimentos levaram a traçar a ligação de Dias Gomes com a opção religiosa ateia. A primeira é uma auto-declaração:

Vamos começar pelo princípio, senão aí vai ser um... Eu e Janete éramos pessoas muito diferentes, talvez por isso nos déssemos tão bem. $O$ nosso casamento durou 33 anos, mas nós tínhamos visões de mundo muito diferentes. Janete era católica, eu sempre fui ateu, eu fui marxista, tive formação marxista e tudo. E ela tinha também um estilo de realismo romântico, e eu sempre fui um realista empedernido. $O$ meu realismo sofria talvez um pouco do fantástico, do absurdo, da mágica. Mas, de qualquer maneira, é uma posição realista. ${ }^{2}$

${ }^{2}$ Matinas Suzuki, Entrevista com Dias Gomes, 1995. 
Dias, portanto, afirma que é ateu marxista, além de reforçar o seu pensamento imanente e não transcendente - o qual ele chamou de realista. Além dessa subjetividade, o outro fato não dito na entrevista é sua filiação ao Partido Comunista do Brasil ${ }^{3}$, que, na época da Guerra Fria, arrogou-se mais fortemente ao marxismo.

Da assunção primária de que Deus não existe parte uma grande variedade de pensamentos ateus, inclusive pensamentos religiosos como os do budismo. A enumeração dessas correntes (como a militante) não nos interessa propriamente, mais importante para os nossos propósitos de análise literária é estabelecer dois referenciais: (1) a do sagrado laico ateu, e a (2) do movimento social ateu no país. Somente assim será possível estabelecer que Dias Gomes está inserido nesse movimento e de que maneira ele dialoga com indivíduos dessa opção religiosa. ${ }^{4}$

Sobre o primeiro ponto "o [...] ateu, portanto, é laico, porque se baseia na natureza como ente não causado, daí o seu porto seguro estar no conceito renascentista de evidência" ${ }^{\prime}$. Ou seja, a existência da natureza como uma entidade autônoma em relação a outras forças é um valor compartilhado do ateísmo em oposição ao pensamento deísta em que a natureza é causada e funciona segundo as regras de alguma entidade (como uma divindade) que também a criou. No pensamento ateísta, a natureza surgiu por um acaso, ou a sua origem não é mais relevante do que conhecer seus mecanismos de funcionamento. Trata-se de uma laicidade no modo como se descreve e se conhece a realidade, porque o foco é naquilo que é imanente e material e não transcendente e metafísico.

\footnotetext{
${ }^{3}$ Marco Roxo; Igor Sacramento, Intelectuais partidos: os comunistas e as mídias no Brasil, 2012.

${ }^{4}$ Denominamos o ateísmo como opção religiosa por este responder a perguntas postas pelo pensamento religioso. Porém, em termos epistemológicos, não o denominamos como uma religiosidade.

${ }^{5}$ Ricardo Cortez Lopes, O nível formal do conceito de Opção Religiosa: agnósticos, religiosos, deístas e ateus, 2017, p. 191.
} 


\title{
3. Os três Roques
}

Para entender propriamente o argumento ateu de Dias Gomes, é preciso mais um movimento antes de passar diretamente ao texto. É necessário abordar a inspiração imanente da escrita e aquilo que ela se tornou no futuro: a novela televisiva. Por isso, são três Roques: o histórico, o Cabo Roque e o Roque Santeiro. Vamos conhecê-los brevemente um a um, pois há uma relação muito forte entre esse trio.

Tal como já mencionado, a peça, originalmente, foi inspirada por um fato histórico, conhecido através da literatura de Euclides da Cunha em Os Sertões:

\begin{abstract}
Aditou-se-lhe depois, mais emocionante, a lenda do cabo Roque, abalando comovedoramente a alma popular. Um soldado humilde, transfigurado por um raro lance de coragem marcara a peripécia culminante da peleja. Ordenança de Moreira César, quando se desbaratara a tropa, e o cadáver daquele ficara em abandono à margem do caminho, o lutador leal permanecera a seu lado, guardando a relíquia veneranda abandonada por um exército. De joelhos junto ao corpo do comandante, batera-se até ao último cartucho, tombando, afinal, sacrificando-se por um morto... E a cena maravilhosa, fortemente colorida pela imaginação popular, fez-se quase uma compensação à enormidade do revés. Abriram-se subscrições patrióticas; planearam-se homenagens cívicas e solenes; e, num coro triunfal de artigos vibrantes e odes ferventes, o soldado obscuro transcendia à História quando - vítima da desgraça de não ter morrido -, trocando a imortalidade pela vida, apareceu com os últimos retardatários supérstites [sobreviventes] em Queimadas. ${ }^{6}$
\end{abstract}

Constrói-se, então, a narrativa de um cabo que se sacrificara pela honra de seu superior, simbolizando o desprendimento da gente do local e representandoas. $\mathrm{O}$ ato transcende o cotidiano, o que gera, tal como no trecho já aventado, subscrições patrióticas, planeando-se homenagens cívicas e solenes. Mas por que esse ato é tão apreciado?

Trata-se do fato de que jamais, nem no presente, nem no passado, a sociedade atribuiu qualquer valor moral aos atos que tenham como único objeto o interesse pessoal do agente. Sem dúvida, a conduta motal foi sempre concebida como produtora de consequências úteis para algum ser vivente e consciente, aumentando sua felicidade e diminuindo seu sofrimento. ${ }^{7}$

\footnotetext{
${ }^{6}$ Euclides da Cunha, Os Sertões, 1982, p. 214.

${ }^{7}$ Émile Durkheim, A educação moral, 2017, p. 76.
} 
O retorno do soldado, porém, causa decepção. Ele volta a ser o Cabo Roque, e não o herói, o que consistiu no que Euclides da Cunha denominou como a sua desgraça. Relevante notar que a farsa citada se resumiu apenas à quebra da imagem do herói pela vida do homem. Mas e se tivesse havido uma exploração comercial do fato? Nesse caso, teríamos exatamente o enredo da peça de Gomes. Acrescentando-se o crescimento econômico ao fato histórico, pode-se observar que, em $O$ berço do herói, o retorno e a reincorporação do cabo à sua comunidade são impedidos pela elite, que deseja seguir lucrando pelo culto cívico. Assim, o acontecimento histórico conta metade do enredo, a outra metade parte do engenho criativo de Dias Gomes.

Na tessitura da peça, a história segue mais ou menos por essa via, mas o autor cambiou o nome do herói para Cabo Jorge, provavelmente por algum motivo ligado à ditadura, pois posteriormente a novela recuperou o nome Roque e a peça foi reeditada também com esse nome. Essa seria a lógica por trás do enredo, mas qual seria a sinopse da peça?

A peça, escrita por Dias Gomes em 1963, mostra o cotidiano de uma cidade do nordeste brasileiro que vive à sombra do majestoso mito do herói de guerra Cabo Jorge, soldado integrante da FEB que atuou na Itália na Segunda Guerra Mundial. A cotidianidade da cidade é focalizada por meio da vida popular: do Vendedor Ambulante, da Mulher Grávida, dos Meninos que brincam na praça, das quermesses da igreja, da praça que congrega a comunidade, das beatas, do registro popular e regionalista da linguagem das personagens. Comunidade que é manobrada pelos chefes da cidade, que se vêem ameaçados pelo retorno do homem-Jorge, pois a corrupta engrenagem progressista, capitalista e política movimentada pela exploração do mito está em risco diante da presença de Jorge. Ele também representa uma ameaça à dignidade dos anais do exército. Por essa razão, o homem-Jorge é sacrificado e o herói forjado permanece vivo. ${ }^{8}$

O herói é construído no mantenimento da mentira e heroicamente dá sua vida pela cidade, que adquire vida (o progresso) como se fosse uma transferência direta. O heroísmo, assim, perde sua voluntariedade, o que cria o paradoxo e a

\footnotetext{
${ }^{8}$ Márcia Letícia Falkowski Déa, Representaçőes do leitor implícito no processo de leitura em textos dramáticos: O berço do herói, de Dias Gomes e O livro de Jó, do Grupo Vertigem, 2005, p. 65.
} 
ironia e explica o título: o berço do herói é porque o nascimento do herói acontece de maneira humana, pela morte.

Diferentemente do Cabo, o Santeiro tem sua morte consagradora supostamente protegendo a igreja municipal do ataque de fugitivos de um presídio, que exigiram uma alta quantia dos moradores para não saquear a cidade de Asa Branca - na peça original, a cidade passou a se chamar Cabo Jorge, o que sintetiza melhor o argumento de Dias Gomes por fundir a cidade à mentira. É possível perceber que a novela, diferentemente da peça, não ataca o mito em geral, mas sim a religiosidade em específico, no caso, o cristianismo em vários níveis (o popular, o vaticanizado e o da teologia da libertação). Tal ataque fica patente porque no decorrer dos capítulos são retratados os cultos, as romarias, o ex-votos, a criação de uma devoção marginal, tudo isso partindo da premissa de uma santidade - algo que muito irrita o padre Hipólito quando descobre a verdade. É possível ressaltar que Roque esculpia santos antes de seu desaparecimento: fabricou literalmente um santo com a sua pretensa morte e a sua presença enquanto vivo acabaria com o santo construído involuntariamente. Ou seja, de profissão, o santo passou a ter um outro relacionamento com o homem.

Portanto, trata-se de três Roques: o histórico, o mito e o santo. Esses três Roques tornam complexo o argumento de Gomes: um é o engano revelado; o outro é a mentira escondida para fins comerciais; e o outro é a mentira santificada. Da mesma maneira, um é o Roque da consagração interrompida, o outro é o Roque em vias de consagração e o outro é o Roque canonizado pelo povo. A novela, assim, mostra o processo de consagração mais adiantado, porque o milagre é o que sustenta o santo Roque, o que é mais crível do que o argumento da peça em si.

Academicamente, poder-se-ia metaforizar que a peça é um resumo e a novela é uma monografia completa. Em um jogo intertextual, a novela se difere da peça apenas na construção do santo e no nome do homem: o restante das 
tramas são personagens e situações não exploradas pela peça, mas que são perfeitamente críveis dentro do universo fictício que foi criado. Por exemplo, a personagem Zé das Medalhas aparece na peça original, e na novela o universo é expandido para a sua família nuclear, com a sua esposa, salva pelo santo na infância, o que a tornou ungida e, de certa maneira, intocável para o marido. É uma situação que não aparece na peça, mas não seria alheia se emergisse.

\section{4. $O$ argumento ateu em $O$ berço do herói}

Conhecido o contexto em volta da peça, podemos agora avançar para as três premissas que sustentam o argumento. Vamos analisar a peça em si, a partir dessas três premissas que vão dando sustentação ao argumento ateu. $O$ primeiro aspecto do argumento é de uma concepção de como a religião guia a percepção das personagens.

\subsection{Premissa 1: Mito religioso}

O berço do herói é uma peça que versa, basicamente, sobre a desmistificação, sendo o mito religioso um dos seus alvos. Por essa razão, vamos conhecer o modo como a religião é conceituada na peça. O primeiro trecho para o qual gostaríamos de chamar atenção está na introdução da obra, na qual é realizada a descrição das personagens, especificamente a do padre Hipólito:

Padre Hipólito é uma figura contraditória. Tão contraditória quanto a própria Igreja Católica. É já de meia-idade e os anos que tem na paróquia lhe permitiram assistir ao crescimento da comunidade. É a única pessoa que possui uma visão global desse desenvolvimento desigual e desordenado em que, sob os rótulos de progresso e civilização, entram, de contrabando, os germens que irão contaminar a futura sociedade dita civilizada e cristã. Consciente disso, padre Hipólito trava uma violenta batalha contra a corrupção dos costumes, que cresce com a própria cidade. Sem uma visão nítida do processo histórico, combate os efeitos, esquecendo as causas. E, contraditoriamente, sua paróquia se beneficia dessa mesma corrupção que ele combate. Essa obsessão, essa ideia fixa - o combate as prostitutas que invadem a cidade -, é a cristalização de uma 
revolta decorrente da consciência que tem de sua impotência para impor a própria concepção moral. ${ }^{9}$

Nesse texto, já é possível observar alguns posicionamentos mais explicitados. Primeiramente, é abordada diretamente a contradição da Igreja, incorporada pelo padre, pois este, devido à sua idade, testemunha o processo histórico da cidade desde antes da ocasião retratada pela peça. Assim, ele não entende que a civilização cristã é contraditória ao capitalismo e ataca as pessoas ao invés do sistema econômico em si.

Também é utilizado, na descrição, o construto psicológico ideia fixa, "[...] uma ideia à qual uma pessoa se subjugou"10. Ou seja, há um subjugar a uma concepção moral, cujo erro seria potencializado pela religião ao buscar sua generalização. Esse traço é reverberado em outra personagem: "Dona pombinha é esposa de Florindo Abelha e mãe de Mocinha. Sua religiosidade se aproxima do fanatismo. Seu moralismo exacerbado é, talvez, um equívoco da mesma religiosidade"11. Todavia, outro vocabulário psicologizante vem em seguida:

Mocinha, filha do prefeito Florindo Abelha, é um temperamento marcado pela frustração sexual. Foi levada ao voto de castidade menos por inclinação mística do que pelo desejo de transformar em culto essa mesma frustração. De maneira curiosa, ela se sente justificada desse modo. A figura que encarna de "virgem abandonada", sublime em sua renúncia, satisfaz inteiramente sua vaidade e aplaca a sua histeria. Esta explode, no final, quando ela se sente roubada e ridícula. ${ }^{12}$

Frustração sexual é um tema recorrente em Sigmund Freud. Ao invés de ir diretamente a ele, vamos permitir que um comentador explique o conceito:

Dependendo do nível da frustração, a sexualidade do sujeito pode estar tão restrita à fantasia inconsciente, a ponto de fazer surgir uma impotência sexual total, uma espécie de prolongamento da fase de latência, e ele perder toda a capacidade excitatória, ou conseguir vivenciar apenas a corrente terna da sexualidade, e toda sua sexualidade ser tingida por um tom terno, puro e sem erotismo. ${ }^{13}$

\footnotetext{
${ }^{9}$ Alfredo de Freitas Dias Gomes, Coleção Dias Gomes, 1990, p. 376.

${ }^{10}$ Edson Passet, Loucura e transtornos: políticas normalizadoras, 2011, p.102.

${ }^{11}$ Alfredo de Freitas Dias Gomes, Op. Cit., 1990, p. 377.

${ }^{12}$ Alfredo de Freitas Dias Gomes, Op. Cit., 1990, p. 377.

${ }^{13}$ Guilherme Freitas Henderson, A impotência sexual na obra de Freud, 2017, p.50.
} 
Mocinha fica presa, portanto, a essa fase de latência, viabilizada por meio de seu sentimento religioso, que não é sua característica principal, como é no padre e na filha do prefeito. Essa leitura psicologizante da religião é bem presente em Feuerbach:

Daí a circularidade que percorre a obra entre a antropologia - uma teoria da essência humana universal (o Homem) - e a psicologia da atitude religiosa (o homem religioso), com o propósito de trazer esta à luz da razão para que as necessidades que lhe dão origem sejam compreendidas como ilusão e acabem por se desvanecer. ${ }^{14}$

Dias Gomes, portanto, analisa as personagens mais religiosas à luz da psicologia, de maneira a demonstrar que a religião é uma atitude psicológica, humana, uma ideia fixa, que é ideia por estar na cabeça humana. O religioso imporia a si e aos outros um pensamento que desvia dos problemas clínicos. Alguns diálogos vão demonstrar isso, como, por exemplo, este: "POMBINHA: medalhinhas de cabo roque. Comprem que é em benefício de nossa igreja. PORCINA: um bilhetinho da tômbola que vai correr daqui a pouco. É pra consertar a igreja que tá pra desabar"15. A religião viabiliza e facilita a troca financeira, pois o que motiva o comprador deve ser o conserto do teto da igreja. Esse parece um presságio em formato de metáfora: é o dinheiro dos fiéis que garante a necessidade do mito religioso permanecer válido, e esse teto seria a ideologia que protege a instituição de uma chuva de críticas. Uma dessas críticas poderia ser dada por essa fala:

PADRE: (Enfiando rapidamente no bolso da batina.) Não tenho o direito de recusar donativos para a igreja, venham de onde vierem, principalmente quando eles me vêm de suas honradas mãos. Mas isso não quer dizer que eu concorde com esse comércio em minha paróquia, nem que isso me obrigue a calar a boca. Vou continuar fazendo sermões contra essas mulheres, e se o prefeito der permissão pra dona Matilde abrir a tal boate - que Deus me perdoe -, reúno todas as beatas da cidade e vou arrebentar com ela na porrada. ${ }^{16}$

\footnotetext{
${ }^{14}$ Adriana Veríssimo Serrão, A pergunta de Feuerbach a Stirner: "que significa 'ser um indivíduo'?", 2013, p. 99.

${ }^{15}$ Alfredo de Freitas Dias Gomes, Op. cit., 1990, p. 384.

${ }^{16}$ Alfredo de Freitas Dias Gomes, Ibidem, p. 447.
} 
O padre aceita o dinheiro provindo do que ele considera pecado, desde que ele seja intermediado pela Viúva Porcina e não pela prostituta. Nesse caso, a religiosidade está chancelando uma atitude contrária à sua moralidade intestina desde que haja uma compensação financeira. Porém, o limiar da aceitação está na institucionalização da indecência: se ela não for marginalizada, o padre não a aceita mesmo que haja a respectiva compensação financeira.

Uma outra fala interessante do padre é quando este descobre a verdade sobre Cabo Roque:

PADRE (parece subitamente iluminado.) É verdade que isso ia cair sobre essa gente como uma praga. Mas há momentos em que nada é tão útil como uma praga para varrer a terra de todo o pecado. Deus ajuda e perdoa, mas também castiga. Quem sabe se não foi Ele quem mandou esse rapaz pra isso? Como um castigo? (sai). ${ }^{17}$

Nesse momento, sob o prisma religioso (uma ideia fixa), o padre interpreta que é preciso uma purificação da sociedade, o que inicia pela boate já aventada. Assim, o padre é basicamente reacionário e atribui a corrupção do mundo aos indivíduos, e não ao capital, segundo o argumento de Dias Gomes. É esse mesmo capital que faz com que Deus seja apenas uma formalidade, na fala do prefeito ao pedir para sua filha redigir um discurso: "FLORINDO: É, veja se dá pra encaixar o nome de Deus aí em qualquer lugar"18.

Um último aspecto interessante acontece mais adiante no enredo, quando está se discutindo as efemérides que são criadas constantemente ao redor de Cabo Roque:

Porcina: e será que Cabo Roque fez mesmo a primeira comunhão?

Malta: eu sei lá. Mas deve ter feito. Não sabe que ele, quando menino, era coroinha?

Porcina: daqui a pouco você vai querer me convencer de que ele era um santo.

${ }^{17}$ Alfredo de Freitas Dias Gomes, Ibidem, p. 470.

${ }^{18}$ Alfredo de Freitas Dias Gomes, Op. Cit., 1990, p. 480. 
Malta: por que o espanto? Tem muita gente que acha. Há até quem garanta que, na guerra, antes de morrer, ele teve uma visão e escutou uma voz: "vai! Avança! Avança!"

Porcina: devia ser algum soldado alemão amigo da onça.

Malta: o povo acredita que era o Senhor do Bonfim. Você vai contradizer o povo?

Porcina: é uma gente muito tola. ${ }^{19}$

É mostrado que há um processo de santificação que está em jogo e que foi finalizado em Roque Santeiro. Na novela, o homem chega quando essa dinâmica se completou, enquanto na peça há uma chegada precoce, tal qual o Roque histórico. No caso da peça, a elite optou por não interromper a consagração em curso.

Vimos que Roque estava se tornando, efetivamente, um santo. Porém, até aquele momento, ele ainda era um mito laico, que remete à nação. Nesse caso, exército e nação se fundem, sendo o herói o intermediário que legitima esse ato.

\subsection{Premissa 2: Mito Heroico/Nacionalismo}

O ato heroico é entendido e vinculado ao sacrifício. No escrito de Dias Gomes, o sacrifício é exaltado e deificado pela elite de Asa Branca. Sinhozinho Malta, símbolo dessa elite, argumenta:

Malta: mas foi preciso que se derramasse o sangue de um herói para que as autoridades federais tomassem conhecimento deste lugar, até então esquecido de Deus e dos homens [...] lutado como lutou para trazer até aqui o progresso, as conquistas da civilização cristã. ${ }^{20}$

Ou seja, é mantida a ideia do sangue derramado, voluntariamente, para um bem maior. A luta no campo de combate adquiriu significações fora dele, de modo que $\mathrm{o}$ ato heroico conquistou individualmente aquilo que a guerra em si tinha ido buscar, como uma cruzada: as conquistas da civilização cristã. Essa

\footnotetext{
${ }^{19}$ Alfredo de Freitas Dias Gomes, Ibidem, p. 397.

${ }^{20}$ Alfredo de Freitas Dias Gomes, Op. Cit., 1990, p. 378.
} 
declaração contrasta imediatamente com aquelas dadas após a descoberta da verdade, que o herói fugira da morte. A resposta do Cabo possui considerações interessantes:

Roque: Não vai querer me passar sermão agora, vai? Sei que, na sua opinião, o que eu fiz foi indigno. Talvez tenha feito coisas ainda piores para não morrer. E o que fizeram comigo, em nome da democracia, da liberdade, da civilização cristã e de tantas outras palavras, nada mais do que palavras. $^{21}$

A indignidade é a palavra-chave. Um indivíduo pode ser digno para si mesmo e isso é nobre na medida em que ele poderia lançar mão de outras opções. O herói, por seu turno, é digno por si e pelos outros, ele não opta por seu bem individual. No caso do Cabo, o mito (nada mais do que palavras) é de que o seu sacrifício fosse trazer bem às pessoas que ele representa em suas dignidades. Porém, ao não perceber esse tipo de relação, Roque opta por desertar. E volta assim que lhe é concedida a anistia.

As interpretações de seu sumiço é que o tornam celebrado, como mostra outra fala de Malta: "Nenhum [homem] fez a cidade festejar, com foguete e banda de música, seu nascimento, sua morte, até sua primeira comunhão. Nenhum acendeu no peito de cada cidadão um falso orgulho, que agora vai ser substituído pelo ridículo e pela vergonha"22. Podemos perceber que ele está projetando com base no seu próprio sentimento, de decepção, que se manifestou com a mesma energia da admiração. Mas o heroísmo volta à baila na seguinte fala de Roque:

ROQUE: Não acredito nisso. Não posso acreditar que um homem seja mais útil morto do que vivo. Do contrário ia ter de acreditar também que todos aqueles infelizes que morreram na guerra foram muito úteis. E que a guerra é uma necessidade porque fabrica heróis em série. ${ }^{23}$

Roque, visivelmente, está colocando o bem humano acima de qualquer bem coletivo (no caso, a nação em guerra). Nesse sentido, a morte é produtora da utilidade mais do que a convivência fraternal, pois o herói, aparentemente, pode

\footnotetext{
${ }^{21}$ Alfredo de Freitas Dias Gomes, Ibidem, p. 446.

22 Alfredo de Freitas Dias Gomes, Ibidem, p. 459.

${ }^{23}$ Alfredo de Freitas Dias Gomes, Op. Cit., 1990, p. 468.
} 
ser fabricado em série, enquanto o homem vivo está destinado a não ser notável se não possuir recursos financeiros - a reificação fica bem evidente.

A certo momento, a peça sai do plano narrativo e cria um número musical:

Entram Malta, Zé das Medalhas, padre Hipólito, todos com enormes barrigas

TODOS: À sombra dessa estátua

uma cidade cresceu,

cresceu, cresceu, cresceu,

Barriga dela cresceu,

de muita gente cresceu.

E agora que fazer

que a estátua virou,

virou, virou, virou,

de novo gente virou

A estátua boceja, se espreguiça. É o próprio Cabo Roque.

Todos

(Apavorados.) Nossa cidade morreu! (Saem todos correndo)

ROQUE

(Dando uma banana.). Antes ela do que eu! ${ }^{24}$

Essa canção brinca, no caso, com os sentimentos das personagens. A estátua é justamente a representação feita objeto, pois o herói sintetiza a comunidade toda em sua valentia. Porém, pode-se observar que o crescimento da cidade também foi acompanhado pelo crescimento dos abdomens das personagens, o que indica que estas aproveitaram-se diretamente da fama do herói para realizar negócios. O interessante é que a imagem do herói é contraposta pelo humano: ele cansa de ficar na posição heroica e faz o contrário do herói: não se importa com a cidade que o cultua.

\footnotetext{
${ }^{24}$ Alfredo de Freitas Dias Gomes, Ibidem, p. 473.
} 
A seguir, podemos retratar algumas reações à revelação da farsa. A primeira é de Mocinha, quando encontra com Roque pela primeira vez após sua volta:

ROQUE: Mas será que sou tão repulsivo assim? Só porque, num momento lá da minha vida, achei que era um homem livre e podia usar minha liberdade como bem entendesse? Então pra que o homem é livre, senão pra isso, pra escolher seu caminho.

MOCINHA: Não estou reclamando de nada. Sei que não tenho direito nenhum. Você seguiu seu caminho e eu, burra, devia ter seguido o meu. Você não tem culpa de nada. A culpa é toda minha. ${ }^{25}$

Roque defende-se afirmando que não mentiu a ninguém, apenas exerceu seu direito a escolha. Mocinha parece representar o povo abdicando da ideia fixa, sem necessariamente estar implicando em alguma espécie de tolice, nos dizeres de Porcina. Ou seja, o povo, o proletariado, pode lidar com a verdade desde que seja exposto a ela.

Em resumo, no argumento de Dias, o herói exerce sua liberdade para não pensar no seu bem individual, o que é o perfeito contrário de Cabo Roque. A cidade desenvolvida representa, assim, a modernidade cristã, que se sustenta por meio da mentira do mito do militarismo, que aceitou viver na mentira. Seria possível também afirmar que este último é a expressão máxima do nacionalismo (algo que o socialismo, historicamente, não aprecia).

Se o mito religioso e o mito heroico são falsos, é possível afirmar que o mais certo é o que pode ser conhecido pelos sentidos. Esse é o objeto da próxima seção.

\subsection{Premissa 3: Inexistência da metafísica}

O materialismo mostra que a metafísica é uma invenção da classe dominante para subjugar a classe dominada. Na peça, isso fica evidente quando

\footnotetext{
${ }^{25}$ Alfredo de Freitas Dias Gomes, Op. cit., 1990, p. 494.
} 
as falas são apreciadas já se sabendo de antemão do engano que se construiu em volta da morte de Roque.

O que seria a metafísica?

A essência, tal como a concebe a Metafísica, é o que uma coisa é verdadeiramente. Visto de perto, percebe-se que aí se confunde o fato de ser algo, com o verdadeiro algo. A pergunta do que é verdade sob aparências, dá origem à resposta que indica tanto a existência como a verdadeira essência. ${ }^{26}$

A primeira fala é a de Porcina: "[...] vocês nem imaginam como eu estou contente. E Roque também, lá do Céu, deve estar"27. Quando a personagem se refere a Céu, é evidente que isso não é verdade, o que torna risível a crença tão fortemente defendida. Da mesma maneira, isso se reflete em outras falas: "PORCINA: também tou achando... (Subitamente:) Meu Deus!... Não, não pode ser! Tou vendo alma do outro mundo! (Leva a mão aos olhos, cambaleia como se fosse desmaiar)"28 e "Malta: É... parece... se não é ele, é o cão disfarçado nele"29. Nessas falas, a interpretação está embasada no pressuposto de que Roque está morto e de que sua volta é um ato religioso (curiosamente, nenhuma personagem considerou a visão como uma aparição benfazeja, como ocorreu na novela).

Outra fala interessante provém de uma canção:

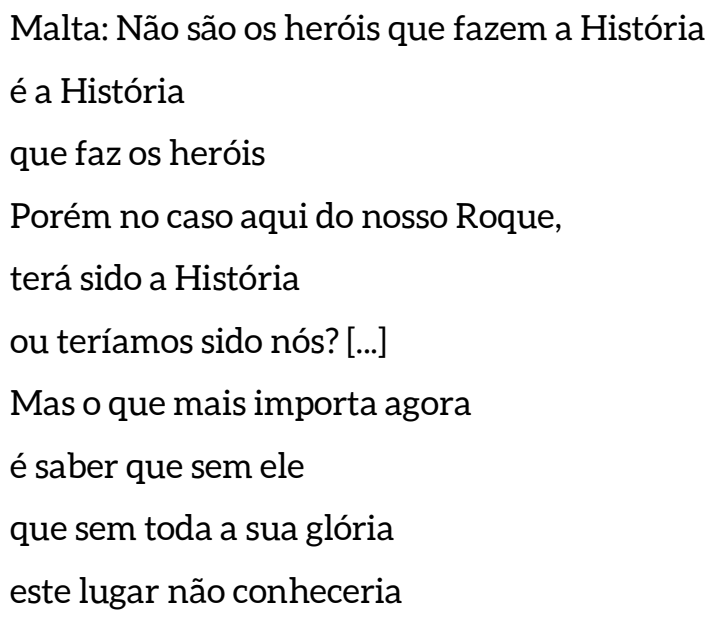

${ }^{26}$ Caio Prado Junior, Teoria marxista do conhecimento e método dialético materialista, 1973, p. 44.

${ }^{27}$ Alfredo de Freitas Dias Gomes, Op. cit., 1990, p. 380.

${ }^{28}$ Alfredo de Freitas Dias Gomes, ibidem, p. 418.

${ }^{29}$ Alfredo de Freitas Dias Gomes, ibidem, p. 435. 


\author{
as maravilhas do capital \\ nem gozaria das delícias \\ dessa civilização cristã e ocidental. ${ }^{30}$
}

Nesse caso, o indivíduo herói não é construído no momento de seu sacrifício, mas sim posteriormente, quando a história o significa. O herói, no caso, nada mais seria do que um meio de prover o acesso à civilização cristã e ocidental. Assim, a sua metafísica não existe, o herói possui um valor utilitário e por isso não se quer revelar a situação que virou farsa.

É curioso que, partindo de uma premissa errônea, a da morte, estabelecese uma constelação de acontecimentos falsos:

ROQUE (Atônito): é espantoso... não sei como é que puderam inventar toda essa história. (Subitamente, começara a rir.) Herói... virei herói... Imagine a cara dessa gente quando me vir... vão pensar que é assombração.

PORCINA: pensando bem, vai ser engraçado... (Ri.) Mudaram o nome da praça, levantaram estátua, escreveram livros, história em quadrinhos, fizeram fita de cinema... e você tá vivo.

ROQUE: (Salta para cima de uma cadeira) Senhoras e senhores, aqui está o batuta! Não morreu, como julgam, porque não há nada de heróico na morte, está vivo, vivo graças à sua inteligência e uma qualidade essencial no ser humano: o cagaço. Teve medo. Mas não um medinho bocó, como qualquer babaquara é capaz de ter. Teve um medo enorme, um medo danado, um medo pai d'égua, como só um herói é capaz de sentir. Nisso está o seu mérito, a sua valentia, porque é preciso muita coragem para sentir um medo tão grande. Ah, se todos os homens fossem capazes de um medão assim, não haveria no mundo lugar para os covardes e a guerra seria enxotada da face da terra. ${ }^{31}$

Roque deseja revelar o ocorrido, ou seja, desvelar a realidade. Ele é como um pesquisador marxista: ele mostra que a personagem histórica é humana pela vivência concreta dos indivíduos. Malta é quem relata a importância da lenda:

MALTA: Atentem nisso: há quinze anos que a cidade vive de uma lenda. Uma lenda que cresceu e ficou maior que ela. Hoje, a lenda e a cidade são a mesma coisa [...] na hora em que o povo descobrir que o Cabo Roque tá vivo, a lenda tá morta. $\mathrm{E}$ com a lenda, a cidade também vai morrer. Tou certo ou tou errado? [...] o vexame de ter cultuado durante quinze anos o

\footnotetext{
${ }^{30}$ Alfredo de Freitas Dias Gomes, Ibidem, p. 382.

${ }^{31}$ Alfredo de Freitas Dias Gomes, Op. Cit., 1990, p. 440.
} 
nome de um desertor [...] o que importa é que ele vem a destruir tudo, tudo que se fez nesses quinze anos. ${ }^{32}$

A lenda é justamente a mentira operacionalizada. E Dias Gomes parece que explica a reação dos poderosos à perspectiva marxista, definida como a destruição da ordem social que lhes favorece. Nesse caso, o interesse material fica explicitado e a repressão do pesquisador acontece no fim da peça:

\author{
MALTA (Canta:) \\ Assim, senhoras e senhores, \\ foi salva a nossa cidade. \\ Com pequenos sacrifícios \\ de nossa dignidade, \\ com ligeiros arranhões \\ em nossa castidade \\ e algumas hesitações \\ entre Deus e o Demônio \\ conseguimos preservar \\ todo o nosso patrimônio. ${ }^{33}$
}

A ideia de patrimônio condensa todo o argumento do livro: no fim, a busca não foi pela verdade, a verdade foi morta para a mentira se tornar real. No fim das contas, o herói é o humano e, se ele for como o herói, ele deixará de ser humano. Portanto, não há uma consagração metafísica, o humano não supera os seus sentimentos, como o medo. Ele é humano e deve ser apreciado enquanto tal.

Ou seja, é preciso um duplo: o metafísico dependeria da transcendência do físico: o herói se desvincula das qualidades humanas e por isso consegue ser consagrado. Mas é preciso o duplo homem para que o processo de sacralização aconteça. Se esse duplo homem não transcende, não existe o processo e nem a metafísica. Quem inviabiliza esse processo é justamente o estado moderno.

\footnotetext{
${ }^{32}$ Alfredo de Freitas Dias Gomes, Ibidem, p. 452.

${ }^{33}$ Alfredo de Freitas Dias Gomes, Op. Cit., 1990, p. 541.
} 


\section{Considerações finais}

A peça O berço do herói, escrita por Dias Gomes, revela-se ao mobilizar contexto histórico e memória (o discurso com sentido referencial) e registrá-los nas obras junto ao seu discurso com sentido não referencial. Da atividade investigativa resultou um argumento ateu, eivado de três premissas. Do ponto de vista sociológico, no caso estudado, o ateísmo não aparece como fenômeno independente, tal como é agora em movimentos como a ATEA ou o ateus.net, que reivindicam o respeito ao ateísmo como uma variedade pública. $O$ ateísmo, aqui, serve de argumento para atacar superestruturas capitalistas, o mito e a religião. É um ateísmo que não pode se qualificar publicamente e que expressa seus argumentos por via de metáforas.

A personagem Roque é, na verdade, retecida por Dias Gomes com seu intuito de observar como funcionaria o sistema capitalista. Se na história imanente o Cabo Roque voltou e o engano foi explicado, na peça, a elite enriqueceu por causa do mito e não deseja que a verdade dos fatos venha a público. Se a desmitificação do herói e da religião tivesse se tornado real, teria se dissipado a ilusão da alienação, o que permitiria o contato com a realidade histórica. Aí se perceberia que, na realidade, o mito da nação oculta os interesses do capital.

Outro ponto importante é o enquadramento psicológico de Dias Gomes ao utilizar termos dessa disciplina, que o aproxima muito das ideias da escola de Frankfurt, que utiliza a psicanálise. ${ }^{34}$ Acaba, assim, por equivaler a religião a uma ideia fixa. A riqueza dessa obra abre muitas possibilidades de estudos de ateus de outras épocas que não a contemporaneidade.

\footnotetext{
${ }^{34}$ Emanuel Messias Aguiar de Castro; Aluísio Ferreira de Lima, O Freudismo e a Escola de Frankfurt: ensaio sobre a relação entre Metapsicologia e Teoria Crítica, 2014.
} 


\section{Referências}

CUNHA, Euclides da. Os Sertões. Abril Cultural: São Paulo, 1982.

DE CASTRO, Emanuel Messias Aguiar; DE LIMA, Aluísio Ferreira. O Freudismo e a Escola de Frankfurt: ensaio sobre a relação entre Metapsicologia e Teoria Crítica. Revista de Psicologia, Fortaleza, v. 5, n. 2, p. 108-123, 2014.

DÉA, Márcia Letícia Falkowski. Representaçőes do leitor implícito no processo de leitura em textos dramáticos: O berço do herói, de Dias Gomes e O livro de Jó, do Grupo Vertigem. 2005. 243f. Dissertação (Mestrado em Literatura Brasileira) Programa de Pós-Graduação em Estudos Literários, Setor de Ciências Humanas, Letras e Artes, Universidade Federal do Paraná, Curitiba.

DIAS GOMES, Alfredo de Freitas. Coleção Dias Gomes. São Paulo: Bertrand Brasil, 1990.

DURKHEIM, Émile. A educação moral. Petrópolis: Vozes, 2017.

HENDERSON, Guilherme Freitas. A impotência sexual na obra de Freud. 2017. 105 f., il. Dissertação (Mestrado em Psicologia Clínica e Cultura) - Universidade de Brasília, Brasília.

JUNIOR, Caio Prado. Teoria marxista do conhecimento e método dialético materialista. Discurso, v. 4, n. 4, p. 41-78, 1973.

LOPES, Ricardo Cortez. O nível formal do conceito de Opção Religiosa: agnósticos, religiosos, deístas e ateus. In: Anais do V Seminário Discente do Programa de Pós-Graduação em Sociologia da UFRGS, 2016: a sociologia diante de novos fluxos e velhos muros. Porto Alegre: Instituto de Filosofia e Ciências Humanas/UFRGS, 2017.

MARX, Karl. A ideologia alemã. São Paulo: Hucitec, 1993. 
MARX, Karl; ENGELS, Friedrich. Manifesto comunista. São Paulo: Boitempo

Editorial, 2015.

MARX, Karl. Manuscritos econômico-filosóficos e outros textos escolhidos. São Paulo: Abril Cultural, 1974.

MARX, Karl. O18 de brumário de Luís Bonaparte. Lisboa: Avante, 1982.

MARX, Karl. O Capital - crítica da economia política. Rio de Janeiro: Ed.

Civilização Brasileira, 2008.

PASSETTI, Edson. Loucura e transtornos: políticas normalizadoras. Ecopolítica, n. 2, 2012.

ROXO, Marco; SACRAMENTO, Igor (Ed.). Intelectuais partidos: os comunistas e as mídias no Brasil. Rio de Janeiro: E-papers, 2012.

SERRÃO, Adriana Veríssimo. A pergunta de Feuerbach a Stirner: "que significa 'ser um indivíduo'?". Philosophica, Lisboa, 2013, n,41 p. 97-108.

SAMOYAULT, Tiphaine. A intertextualidade. Tradução Sandra Nitrini. São Paulo: Hucitec, 2008.

SUZUKI, Matinas. Entrevista com Dias Gomes. Memória Roda Viva. 1995.

Disponível em:

http://www.rodaviva.fapesp.br/materia/405/entrevistados/dias_gomes_1995. htm. Acesso em: 03 abr. 2019.

\section{Referência para citação deste artigo}

LOPES, Ricardo; MARTINEZ, Yana. Um estudo sobre três premissas do argumento ateu na peça $O$ berço do herói, de Dias Gomes. Revista PHILIA | Filosofia, Literatura \& Arte, Porto Alegre, volume 1, número 2, p. 505 - 525, outubro de 2019. 